Tér és Társadalom 15. évf. 2001/1. 25-38. p.

Tér és Társadalom

XV. évf. 2001 1: 25-38

\title{
A TERÜLETI EGYENSÚLYOK
}

\author{
(Spatial Balances)
}

\section{BARTKE ISTVÁN}

Kulcsszavak:

regionális politika, területfejlesztés, térmodellek

A területi egyensúlyi növekedés - nemzetközi fogalomhasználat szerint - a különbözố régiók eltérố fejlettségi színvonalának közelitésére ható folyamat, vagyis a kevésbé fejlett területeknek a fejlettebb régiókét meghaladó ütemũ növekedése. Ez a felfogás a területfejlesztési politika müködési körét a gazdaságra szükiti le. E hibaforrás megszüntetésére olyan modell készült, amely a koncepcióalkotásba szélesebb társadalmi szférákat is bekapcsol.

A területfejlesztési politika feladatának általában a kiegyensúlyozott területi fejlődés elömozdítását tekintik. Ennek megvalósitására lehetségesnek, sőt szükségesnek tartják a társadalmi beavatkozást a spontán regionális folyamatokba piacgazdasági feltételek között is. Gyakran a területek közötti kiegyenlitésröl beszélnek, e mögött - jobb esetben - leegyszerüsítési törekvés húzódik meg. Elöljáróban le kell szögezni, hogy a regionális egyensúlyi növekedés társadalmi előmozdítása és a területi különbségek kiegyenlítése között minőségi eltérés van, a két kifejezés semmiképpen sem használható szinonimaként.

\section{A teriuleti közelítés, mint a regionális politika (egyik) alapelve}

A területi egyensúly fogalmának definiálásához a regionális politika korábbi (több évtizedes) gyakorlatának néhány sajátosságából indulunk ki. A területfejlesztési politika kialakulásának egyik jellemzője a fokozatosság, az, hogy annak elöször néhány eleme jelent meg, beépülve a gazdaság- és társadalompolitikába. A XX. század folyamán, különösen annak második felétől a jelzett elemek száma egyre gyarapodott, a területfejlesztési politika növekvő számú eleme integrálódott, intézményesült. Ebben a fejlödési menetben kezdeti cél a gazdasági-társadalmi fejlődés lokálisan is megjelenő egyes zavarainak elhárítása volt, amelyek egyaránt veszélyeztették a gazdaság müködését és a társadalmi-politikai közérzetet. Az említett zavarok Európában is részint az 1920as, 30-as évek válságának folyományai voltak, részint - az előzőtól nem teljesen függetlenül - a felgyorsult gazdasági szerkezetváltásban gyökereztek. Jellemző példák: a szénbányászat visszafejlődése által keltett térségi depresszió következményeinek mérséklésére tett intézkedések Nagy-Britanniában, vagy a nagyvárosok (mindenekelött London és Párizs) növekedésének különböző eszközökkel történt korlátozása. A regionális politikák intézményesülésével az 
egyedi célok szélesebb és általános elveket is tartalmazó rendszer elemeivé váltak, az általános elvek közül a területi közelítést indokolt kiemelni.

A területfejlesztési politika fejlődésének és intézményesülésének másik iránya a közép-európai fỏderális berendezkedésủ államokra jellemző (Ausztria, Németország, Svájc). A regionális fejlődés egyedi és.típusos társadalmi-gazdasági problémái természetesen ezekben is hasonlóak lehettek, mint a korábbi példaként említett nyugat-európai országokban; az érintett államok adminisztratív berendezkedése révén azonban „eleve” adva volt a területfejlesztési intézményrendszer gerincének tekinthetô regionális (tartományi) szint; a területfejlesztési feladatok a lokális szintről kiindulva fogalmazódtak meg, és komplex formát öltöttek. Németországban pl. az 1920-as évek folyamán széles körủvé vált az ún. Landesplanung, amely elsősorban a helyi (tartományi) erőforrásokra alapozott tervezést jelentett. A II. világháború után a regionális fejlesztés együttes tartományi és szövetségi feladattá vált és alkotmányban rögzítették az egyenlö életfeltételekhez való jogot (Hajdú 1995), amelynek anyagi hátterét a területek közötti gazdasági közeledés adja.

A területi közelítés olyan alapelv, amely egyaránt jellemző a nyugat- és középeurópai országok regionális politikájára. (Talán nem kell bizonygatni, hogy az az országok további széles körében is megfogalmazódott.) Logikailag is levezethetö, de szakirodalmi források alapján is megállapítható (Rechnitzer 1993), hogy az utóbbi évtizedekben fokozott figyelmet kapott „endogén fejlesztés” elve föként a föderalizált államok területfejlesztési gyakorlatában gyökerezik, és ugyancsak a területi közelítést szolgálja. Az európai integrációs szint (EU) regionális politikájának szintén egyik vezetô elve a területi közelítés (Horváth 1998), amelyet a központi támogatási eszközök és a helyi (endogén) eröforrások kombinálásával, mindenekelött regionális szinten kívánnak megvalósítani.

Említeni érdemes még - a "teljesség” kedvéért is - az 1920-as évek oroszszovjet gyakorlatát. Az Oroszországi Kommunista (bolsevik) Párt 1921 márciusában tartott $\mathrm{X}$. Kongresszusa előadói beszédében a következők hangzottak el: „,.. a nemzeti kérdés olyan rendszabályok kidolgozását követeli, amelyek az elmaradt nemzetek és népek dolgozó tömegeinek gazdasági, politikai és kulturális haladását megkönnyítik, amelyek módot nyújtanak nekik arra, hogy utolérjék az előrehaladt proletár Közép-Oroszországot" (Sztálin 1951, 47). Egyfajta területi közelítési feladat ebben is megfogalmazódott, azonban szigorúan centralizált alapon. Az előadó ugyanis élesen visszautasította azokat a hozzászólásokat, amelyek a „,nemzeti-kulturális önrendelkezést” firtatták.

\section{Modellezési lehetöségek}

Az elöző fejezetben vázoltak alapján felvetỏdik az a kérdés, hogy miben áll a területi közelítés, a területi fejlödés mely tartalmi elemeire értelmezhetö; egyáltalán 
a területek közötti különbségek milyen tényezői vehetök számításba, ezek közül melyek azok, amelyek csökkenthetők vagy mérséklésük indokolt. A probléma vulgáris interpretálásakor a múltban gyakran találkozhattunk a térségek közötti különbségek „kiegyenlítésének” fogalmával, az „egyenletes területi fejlesztés” célként való megjelölésével. Nem kell komolyabb szakértelem annak belátásához, hogy a kiegyenlítés képtelenség olyan ismérvek esetén, mint a természeti-földrajzi viszonyok, az infrastruktúra szerkezete stb., sőt egyes neves szakemberek a gazdasági kategóriákat (mint pl. a fajlagos jövedelem) tekintve is lehetetlennek, de legalább is kérdésesnek tartják a területek közötti közelítés lehetőségét (StöhrTödling 1977). Mindezek ellenére a „teruileti kiegyenlítés” ma is gyakran megjelenik a napi sajtóban, egyes politikusok nyilatkozataiban vagy más alkalmakkor.

A szakirodalom, árnyaltabb megfogalmazást alkalmazva, megjelöli azon tartalmi elemeket, amelyekre a „közelítés”, ritkábban a „kiegyenlítés” a valóságban alkalmazható. A fejlett nyugati országok regionális politikájában leggyakrabban az életszínvonal területi különbségeinek csökkentése fogalmazódott meg célként. Ehhez kapcsolódott a régiók közötti kiegyensúlyozott növekedés fogalma. E közelítések a gazdasági kategóriák szerepét hangsúlyozták a regionális politikában. Számos, itt nem részletezhető szakirodalmi forrás tanúsága szerint az 1960-as években, a magyar regionális kutatók is leszámoltak az egyenletes területi fejlesztés fogalmával, helyette egyensúlyi, arányos területfejlesztésröl, illetve az indokolatlan területi különbségek megszüntetéséröl irtak. Ennek is betudhatóan letisztult kormányzati álláspontot tükröz az 1971. évi kormányhatározat a területfejlesztés irányelveiről, amennyiben az egyik fỏ célként a lakosság életkörülményeinek területi közelítését túzi ki. A Német Szövetségi Köztársaságban és Svédországban az 1970-es évek elején a teruleti közelítési célt szintén gazdagabb, illetve pontosabban definiált tartalommal, az „egyenletesebb életkörülményekben" jelölték meg, beleértve a foglalkoztatási lehetőségeket, a szociális-kulturális, kereskedelmi szolgáltatásokhoz való hozzájárulást, a megfelelö környezetet (Stöhr-Tödling 1977). A hivatkozott szerzőpáros idézett munkájában ugyanakkor felveti: a területi egyenlőség fogalmát az említett társadalmi-gazdasági tényezőkön túl ki kell terjeszteni az egyének és a kisebb társadalmi csoportok ahhoz való jogára is, hogy ellenőrizzék a jólétüket befolyásoló külső gazdasági, technikai, kulturális stb. hatásokat. Ez lényegileg azt jelenti, hogy a területi egyenlöség fogalmába beletartozik az egyes térségek egyenlö esélye a másoktól való különbözéshez is.

Vizsgáljuk meg ezek után, hogy a vázolt egyenlőségi-közelítési tartalmak alapján milyen regionális modellek szerkeszthetők. Az első a területi egyensúlyi növekedés modellje. 
A nemzetközi és a hazai szakirodalomban általánosan elterjedt szóhasználat szerint ez nem más, mint a különböző régiók eltérő fejlettségi színvonalának közelítésére ható folyamat, nevezetesen a kevésbé fejlett területeknek a fejlettebb régiókét meghaladó ütemü növekedése. A folyamat körülírása is jelzi, hogy a regionális egyensúlyi növekedés gazdasági tartalmú kategória, nincs közvetlen kapcsolata olyan társadalmi szférákkal, mint a népesség számának alakulása, a környezetvédelem, a kultúra stb. Ez a felfogás a területfejlesztési politika kompetenciáját, müködési körét - elsö közelítésben - a gazdaságra szükíti le. Feltételezi egy oldalról, hogy a társadalom térségi viszonyai a gazdaság területi elhelyezésén keresztül kellően szabályozhatók, más oldalról a társadalmi viszonyok homogének, tehát azok visszahatása a gazdaságra területileg nem differenciált.

A gazdaság középpontba helyezéséböl adódó hibaforrások egy másik egyensúlyi modell felállitásával küszöbölhetők ki. A körülírt dinamikus modelltöl megkülönböztetendő ezt nevezhetjük - ugyancsak első közelítésben - regionális szerkezeti (egyensúlyi) modellnek. Lényege, hogy nem elsősorban a különbözö térségek (területi rendszerek, területi közigazgatási egységek, régiók) horizontális (egymás közötti fejlettségi) viszonyait vizsgálja, hanem az egyes térségeken (településeken, régiókon stb.) belül a szerkezeti tényezők, mint természet, müvi környezet, társadalom, gazdaság egymásra épülését, azok mintegy vertikális kapcsolatait. Nevezhetö ez statikus egyensúlyi modellnek is, mert az említett szerkezeti tényezök közötti mennyiségi és minöségi viszonyok meghatározóak mind a gazdasági kapacitások nagysága, mind a lakossági igények kielégítése, egyszóval a valamely időpontra jellemző társadalmi-gazdasági fejlettség szempontjából. A statikus modellt a tényezők közötti aránykövetelmények átalakulása, a belsỏ egyensúlyviszonyok megbomlása (ami fejlödést serkentő tényező is lehet), majd helyreállása dinamizálja; e két egyensúlyi modell között - a gazdasági szférában - megteremthető a kapcsolat.

Egyes hazai regionális kutatók viszonylag korán felismerték, hogy a vázolt alapgondolat révén kibövülhet a területi politika eszmeköre, a gazdaságin túl más szempontok is beépithetök abba. Enyedi György már évtizedekkel ezelött hangsúlyozta azt a követelményt, hogy a területfejlesztési politikát ne zárják be a gazdasági kategóriák közé, hanem szélesebb társadalmi szférákra is terjesszék ki azt. A társadalom és a gazdaság területi kapcsolatain túl értelmezzék a társadalom és a természeti környezet viszonyát is. A természetet ne egyoldalúan, mint anyagi erőforrást és munkatárgyat (ill. munkaeszközt) vegyék számításba, hanem mint a társadalmi és az egyéni lét általános feltételét is. Ez a gondolata már tủkrözi a statikusnak nevezett területi egyensúlyi modell egyes elemeit, amit a következő idézet is igazol. A szerzönek a Földrajzi Közlemények 1972. évi 4. számában írt "A társadalom és földrajzi környezete" c. tanulmányában - egyebek mellett - a következőket olvashatjuk: „A természeti és társadalmi folyamatok közötti 
egyensúlymegbomlásokat a gazdasági tervezés eszközével is meg kell kísérelnünk helyreállítani. A gazdasági tervezés számtalan egyensúlyi problémát kezel, mint például a beruházási javak és a beruházási igények közötti egyensúly kérdését, a piaci kínálat és a fizetöképes kereslet egyensúlykérdését stb. és egyik - bár sajátos egyensúlyi problémaként értelmezhetnénk a társadalmi hatások és a földrajzi környezet közötti egyensúly problémákat." (Enyedi 1972, 298) A hitelesség kedveért ehhez hozzá kell füznünk, hogy más regionális kutatók - nagyjából egyidőben ugyancsak feszegették a statikus területi egyensúly különbözỏ vonatkozásait.

Példaként említhetö a területi egységek, úgy is mint területi rendszerek gazdaságának (struktúrájának) vertikális egyensúlyi elv szerinti rendeződése, amelynek tényezői: a megfelelö arány a termelő és a „nem termelö” ágazatok között; az előbbiek, valamint a lakosság jövedelmi viszonyai és anyagi-kulturális ellátásának feltételei (kapacitásai) között, továbbá a termelés és településszerkezet, valamint az infrastruktúra fejlettsége között stb. Az elv érvényesülése különböző területi mérlegek alkalmazásával ellenörizhetö és tervezhető. Ilyenek: a munkaeröés vízmérleg, az építési kapacitásmérleg, továbbá a lakossági csoportok fajlagos létszámára vetített ellátottsági mutatók stb. (Bartke 1972).

\section{1. ÁBRA}

$A$ regionális szerkezeti modell tényezö $i$

(Factors of the Regional Structural Model)

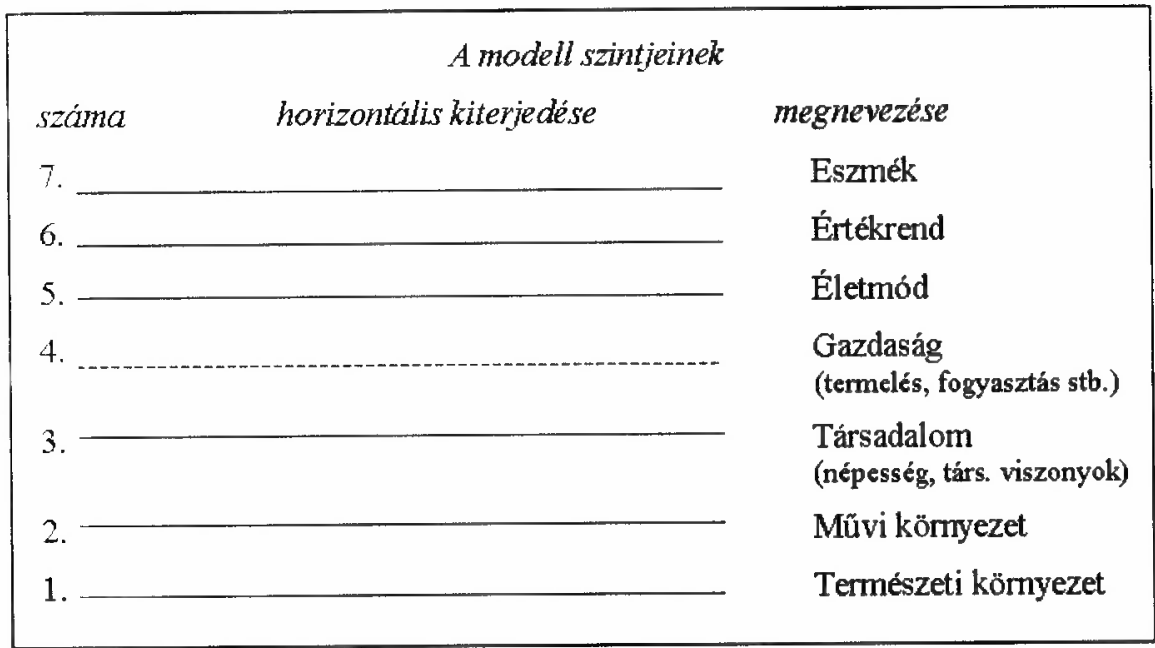

Forrás: Bartke 1999, 4.

Enyedi György későbbi munkáiban is rendszeresen visszatér a természeti környezet és a társadalom viszonyának (egyensúlyi) problémája. A kérdéskörbe további tényezöket is bekapcsol, amikor pl. a természeti, illetve kulturális környezeti elónyöket az anyagi fogyasztás növelésének lehetséges alternativájaként állítja párhuzamba, utalva ennek korlátaira is. Ez a problémafelfogás olyan 
regionális egyensúlyi modellbe illeszkedik, amelynek anyagi tényezői mellett kulturális elemcsoportjai is vannak, jelen példában az eltérő lehetőségek közötti választás, társadalmi értékelés, értékrend alapján. A kibővült területi egyensúlyi modell tehát szellemi vagy részben szellemi tényezöket is magába foglalhat. Enyedi György a „Regionális folyamatok Magyarországon” c. 1996-ban megjelent könyvében a "teljes környezet” elemeiként sorolja fel a fizikai (természeti), a társadalmi-gazdasági (ezen belül a múvi) kömyezetet, amelyet kiegészít a mentális környezeti elemmel. A könyv 92. oldalán a következőket olvashatjuk: „,... a mentális környezet: a környezet tükröződése tudatunkban, a kömyezethez füződö értékek. Eszmék, ideológiák, ízlések környezete. Az egyéneknek a környezettel kapcsolatos döntéseit ez a mentális környezet kondicionálja." Vázolható olyan regionális szerkezeti modell, amely - egy változat szerint - a következö tényezőkből épül fel (v.ö.: Bartke 1994):

Kiemeljük a fenti regionális szerkezeti modell hat sajátosságát, majd részletesen kifejtjük azokat.

a) A modell tényezöi közötti vertikális kapcsolatok változó térségi kiterjedésre (földrajzi pontokra, régiókra stb.) értelmezhetők;

b) az említett vertikális kapcsolatok mennyiségileg és minőségileg meghatározottak, és mint ilyenek, egyensúlyi viszonyoknak foghatók fel;

c) az egyes tényezők (szintek) között logikai és funkcionális összefüggések vannak, amelyek különösen erősek a szomszédos szintek között, de kiterjednek az egymástól távolabb elhelyezkedỏ tényezőkre is;

d) az egyes tényezók horizontális kiterjedése változó, ezért a közöttük levő vertikális kapcsolatrendszer eltérỏ minőségü térségi kombinációkban fejeződik ki, amelyekben harmonikus viszonyok vagy feszültségek testesülnek meg;

e) a különböző térségi kombinációkra jellemző feszültségek együttese döntően hat a területfejlesztési politika céljaira;

f) végül azok a térségek tekinthetök funkcionális régióknak, amelyeken belül a modell hét tényezője közötti vertikális kapcsolatok harmonikusak, illetve egyensúlyuk megteremthetö.

A részletes kifejtésre a kiemelés sorrendjében a következő fejezetben kerül sor.

\section{A regionális szerkezeti modell leírása}

a) A modell - első közelítésben - horizontális kiterjedésủ tényezöi egymás fölött jelennek meg, lehetôvé téve logikailag a vertikális viszony definiálását. Maguk a „horizontális” tényezők származási szempontból - szintén elsỏ közelítésben homogén elemekböl épülnek fel, amelyek az általuk generált térben egyenlötlenül helyezkednek el. Egyedül a természeti környezet tekinthetö minden irányban folytonosnak; a mủvi környezet (2. szint) elemei, mint a magas- és mélyépítmények 
kisebb-nagyobb mértékben összefüggő csoportjai (üzemi, intézményi és lakóépületek, közlekedési, kommunikációs hálózatok, közmüvek stb.) a természeti környezetre épülnek rá (szokás ezeket összefoglalóan infrastruktúrának nevezni), annak egy részét foglalva el. A társadalom (egyének és csoportok) települése döntően az infrastruktúra elhelyezkedéséhez igazodik, munkavégzésre, helyváltoztatásra azonban igénybe veheti a természeti környezetnek a múvi elemek által le nem fedett egyes részeit is. A modell tényezöi közötti vertikális viszony földrajzi pontokra, illetve különbözö kiterjedésü térségekre értelmezhetö. Globális közelítésben kicsi az esély arra, hogy földrajzi pontonként vertikális kapcsolat alakuljon ki valamely természeti, mủvi és társadalmi elem között. A pontszerú kiterjedéstöl a horizontális (térségi) nagyság felé haladva az említett esély nő. Ez a megállapítás vonatkozik a gazdaság térbeni megjelenésének lehetőségére is. A korszerü gazdaság lényegi sajátja a (területi) munkamegosztás, ezért a 4. tényezö lokális megjelenése (mint vertikális viszony) mellett hasonló fontosságú a különböző tartalmú gazdasági tevékenységre képes földrajzi pontok (régiók) közötti, horizontális kapcsolatrendszer. A modell tényezöinek „belsö” mobilitását tekintve a gazdaságé (amelyhez a termelés, forgalom, fogyasztás stb. tartozik) a legnagyobb. A többi (5., 6. és 7.) tényezöt a modell a társadalomból emeli ki, területi szerkezetük keretét a társadalom területi elhelyezkedése adja. Ezen belül azonban a kép még differenciáltabb; a jelzett tényezök belső tagozódását az azonos életmódot folytató, azonos eszméket és értékrendet elfogadó emberek különbözö csoportjai együrttesen formálják. Ezek elörebocsátása után megállapítható, hogy földrajzi pontonként az esetek nagy részében nem jön létre vertikális viszony a modell tényezői között. Értelmezhető kapcsolat keletkezik viszont a települési szórványok (magukban álló tanyák) esetében, amikor pl. a tanyán élök (egyén, család, háztartás) mezőgazdasági földterület, mint természeti erőforrás megmüvelésével stb. gazdálkodási tevékenységet folytatnak, a társadalmi csoportra méretezett művi eszközökkel (hajlék stb.) rendelkeznek, életmódjuk tükrözi anyagi körülményeiket és értékfelfogásukat. A pontszerü horizontális kiterjedésủnek tekintett (tanyai) vertikum a 4 . tényezőn keresztül illeszkedik a piacba, tartja a kapcsolatot más földrajzi pontokkal, térségekkel; a gazdasági tényező által kiterjesztett (horizontális) mozgástér teszi számára lehetővé termékfeleslegének realizálását, jövedelmének megszerzését, illetve termelésének és létének periodikus megújítását. A naturálgazdálkodás absztrakt feltételei között a gazdaság kapcsolatteremtö szerepe hiányzik, a gazdálkodás önellátó jellegü.

Kiterjedtebb térségek, a települések szintjén a tényezők közötti (vertikális) mennyiségi kapcsolatok megsokszorozódnak, minöségileg átalakulnak és új tartalmakkal bővülnek. Nem mehetünk bele annak taglalásába, hogy a sokszorozódás és a minőségi átalakulás milyen változásokon megy keresztül a település méretének növekedésétöl függöen, csak a „település” néhány általános 
tartalmi sajátosságát vehetjük szemügyre. A vertikális kapcsolatok egyszerü mennyiségi sokszorozódásán túl minőségi változást okoz, hogy a település társadalma szervezett emberi közösség, amely magatartásszabályokat hoz létre, intézményeket mủködtet a közérdek érvényesítésére. Így tehát a közérdeket képviselő preferenciákkal bővül a modell 6. szintje, miközben az egyének megtartják saját, ideológián, életmódon alapuló értékeiket. A közösségi és egyéni értékek (érdekek) ütközhetnek; ez esetben a korrekt településirányítás az előbbieket részesíti előnyben. Miközben tehát egyénenként (kisebb-nagyobb társadalmi csoportonként) sajátos marad a modell szintjei közötti kapcsolat minősége, a közös magatartásszabályok e körben a vertikális viszonyokat homogenizálják (kedvezö esetben, vagyis, ha a szabályok megtartása mindenkire egyformán kötelezỏ). Ugyanakkor ezeken keresztül normalizálható a viszony a települési társadalom és természeti környezete között (ésszerü területhasználat elöírásával, az egyéni károkozás lehetöségének mérséklésével, kiiktatásával). A közösségi eszközöknek a település közös értékeit követő elosztásán keresztül növelhetö a jövedelemtermelöképesség, bővíthető az infrastruktúra és a szolgáltatások stb. A település is szükségszerúen bekapcsolódik a területi munkamegosztásba, emellett azonban annak nagyságától függően - szükebb vagy tágabb körben - kiépülhet és hatékonyan üzemelhet a helyi szükségleteket kielégítő termelés, szolgáltatás. Ezen a térségi szinten ugyancsak közvetlen és közvetett kapcsolat valósulhat meg a természeti, a mủvi környezet és a társadalom között.

Településcsoportok (munkaerő-vonzáskörzetek, kistérségek) szintjén a vertikális kapcsolatrendszer sajátossága részint a települések többszöröződésében (és mindegyik „autonóm” belső viszonyaiban), részint azok egymást kiegészítő jellegében van. Nincs kizárva a társadalom egységes (közigazgatási) szervezésének lehetösége sem; ilyen esetekben az értékek, a preferenciák további elemekkel egészülnek ki. Hasonló megállapítás érvényes a regionális szintre azzal az eltéréssel, hogy abban a kistérségek többszörözödnek, és magasabb szintü funkcióhoz kötődnek a kiegészítő jellegủ vertikális viszonyok. A közigazgatási szervezet regionális szinten is - adott térséghez kötödö - érdekeket generál és azokat részben preferenciák meghatározásával érvényesíti.

b) és c) A szintek (tényezök) közötti vertikális viszonyok funkcionális és logikai elven szerveződnek. A funkcionális kapcsolatok legkézenfekvőbb típusa az anyagi termelés által valósul meg, mivel az meghatározott természeti elemek (erőforrások), múvi tényezők (épületek, gépek) és társadalmi erőforrások (munkaerő) lokális kombinációja által jön létre, többnyire szervezeti keretekbe koncentráltan. Ez a vertikális kapcsolat egyensúlyi viszony is, mivel adott termék (termelőeszköz, fogyasztási cikk) elöállítása a felhasznált (természeti, tőke- és humán) erőforrások meghatározott aránya mellett lehetséges. Az optimális arányoktól való eltérés bizonyos keretek között - nem teszi lehetetlenné a termelést, viszont befolyásolja 
annak hatékonyságát. A termelékenység (hatékonyság) foka tehát a modell különböző szintjeiben megjelenő termelési tényezők közötti (vertikális) kapcsolatok minőségi mutatója. A vázolt összefüggés természetesen nemcsak egy-egy termék eloállítására érvényes, hanem a szervezeti keretekben (vállalatokban) folyó termelötevékenységre, továbbá a település és kistérség, régió egészére, amelyekben sok, különböző profilú és nagyságú vállalat müködik. Így tehát a termelés hatékonysága logikailag településenként, kistérségenként, régiónként is mérhető; gyakorlatilag akkor, ha ismertek az erőforrás-ráfordítások, más oldalról az elért illetve a piacon elismert termelési eredmények értékadatai. A területi hatékonyság tartalma további tevékenységek bekapcsolásával gazdagítható. A gazdaságon belül változó területi szinteken újabb egyensúlyi kapcsolatok mutathatók ki, mint pl. a jövedelemszerzés (termelés) és -felhasználás megfelelése (hosszabb időtávon), vagy ennél jellemzőbb pl. a jövedelem-felhasználás, az életmód és az értékrend viszonya. A takarékos gazdálkodás (jövedelem-felhasználás) mint meghatározott értékeket kifejező és életmódbeli sajátosságot tükröző magatartás a tőkeforrások, a beruházások növelésére hat (gyarapszik a müvi környezet) és fellendül a gazdaság. A nem anyagi szolgáltatások szférájában is tipikus és változó térségi kiterjedésủ vertikális kapcsolatok definiálhatók. Településszinten ki kell emelni az alap(fokú) ellátás megvalósítását lehetơvé tevő kapcsolatrendszert a természeti elemek egy csoportja, a rájuk települt szolgáltató létesítmények (mint a müvi és társadalmi környezet összetevői), valamint a szolgáltatást igénybe vevő helyi társadalom között. Egyensúlyi viszony akkor jön létre, ha az alapellátási (lakás, közmủ, általános iskola, háziorvosi rendelő stb.) kapacitások összhangban vannak a lakossági igényekkel, mennyiségi és minőségi szempontból kielégitik azokat, és nem maradnak fenn tartósan kihasználatlan kapacitások sem. A magasabb (közép-, felső) fokú szolgáltatások csak nagyobb települések (megfelelő szảmú népesség) esetén jöhetnek létre, máskor több, kisebb település együttesen veszi igénybe a többnyire központosan nyújtott középfokú szolgáltatásokat. Így e körben az egyensúly vonzáskörzetekre, kistérségekre együttesen értelmezhetó. Hasonló térségi egyensúlyviszonyok alakulhatnak ki a munkaerö-ellátásban is, mivel az egyedi településeket részben munkahely-többlet és lakóhely-hiány (illetve fordított viszonyok) jellemezhetik. Tágabb értelemben egyensúlyi kapcsolatnak fogható fel a különböző térségi szinteken (települési, kistérségi, regionális szinten) mủködó közigazgatási szervezetek által képviselt értékek, preferenciák és a lakosság hagyományai, életmódja, a gazdaság fejlesztési lehetőségei, a természeti környezet állapota stb. közötti viszony. Egyensúlyról akkor beszélhetünk, ha az előbbiek (vagyis az irányítási preferenciák) összhangban vannak az utóbbi adottságokkal. Fontos egyensúlyi tényező a közösségi fejlesztési elgondolások és a rendelkezésre álló anyagi (pénzügyi) eszközök viszonya is. 
d) és e) A modell szintjeinek már említett eltérő horizontális kiterjedése miatt elméletileg elöfordulhat a tényezők bármilyen, egyensúlyt vagy egyensúlytalanságot hordozó lokális kombinációja. Egyensúlytalanság ellen hat a hosszú távú „szerves” fejlődés, a vertikális kapcsolatok logikai és funkcionális meghatározottsága az egyes tényezök közötti szoros kölcsönhatások miatt. Valamely térség hosszú történelmi időszak alatti töretlen fejlödése esetén vertikális egyensúlyi állapot alakul ki és marad fenn mindaddig, amíg valamely külső beavatkozás nem térít el a „spontán” folyamatoktól, nem torzítja a tényezök közötti kapcsolatokat. Egyensúlytalanságot okozhat voluntarista társadalompolitika, önkényesen és adminisztratív módon megszabott, a területi adottságokat figyelmen kívül hagyó vagy éppen erőszakosan megváltoztatni kívánó preferenciarendszer, de nemzetközi hatalmi kényszer is (országterületek átszabása stb.). A vertikális egyensúlyi állapot (a tartalmilag és kiterjedésben megfelelő területi egységekre értelmezve) többek között azt jelenti, hogy a gazdaság fejlettsége, a népesség életminősége összhangban van a természeti és társadalmi feltételekkel, a művi környezet fejlettségével, más közelítésben pedig az adott térség társadalmának eszmei meggyőződésével, értékrendjével és életmódjával stb. Egy oldalról tehát a feltárt területi egyensúlyhiányokból kiindulva levezethetök a regionális politika céljai.

A társadalmak általános törekvéseire alapozva a vertikális egyensúlyviszonyok centrumát az életminőség jelenti, az anyagi és a szellemi tényezők közötti összhang vagy annak hiánya az említett szempontból minösíthető. Más oldalról viszont az életminőség anyagi összetevőjét, az életszínvonalat tekintve módosul a kép. Az utóbbi kategória a termelés és szolgáltatás eredményének (a jövedelemnek), valamint a népesség számának és szerkezetének - első közelítésben - mennyiségi viszonya földrajzi pontonként, illetve különféle térségenként. A modell harmadik és negyedik szintjének (tényezöjének) kapcsolatában gyökerezik. Az életminöségre azonban ezeken túl más tényezők is hatnak, amelyek erösségét illetően fontos az adott társadalom értékfelfogása. Lehetnek olyan (területi) társadalmi csoportok, amelyek többre becsülik a szabadidö, mint az anyagi javak mennyiségének (jövedelmüknek) a növekedését; alternatívaként szembeállítható egymással a természeti környezet nagyobb tisztasága, vagy az anyagi fogyasztás többlete stb.

Történelmi tapasztalat, hogy miközben a tényezök közötti vertikális egyensúly általánosan megvalósul, jelentős horizontális különbségek maradhatnak fenn, vagy jöhetnek létre az életszínvonalban. Természetesen az életminőségben is, de korábbi gondolatmenetünknek megfelelöen az a gazdasági feltételek mellett egyéb tényezöktöl is függ, olyanoktól, amelyek egy-egy földrajzi pont vagy terület népességének elidegeníthetetlen és nem homogenizálható tulajdonsága, ezért „külsö” befolyás alá nem vonhatók. Visszatérve az életszínvonal horizontális különbségére és azok változására, fö okként a müszaki fejlödés és azzal párhuzamosan a társadalmi viszonyok átalakulása emelhető ki. Az ipari forradalom, 
majd később a tercier szektor arányának növekedése gyökeresen átrendezte a gazdasági fejlődés térségi szféráit, azonban nemcsak a horizontális (strukturális, jövedelmi stb.) különbségeket tette kirívókká, hanem felborította a vertikális térségi egyensúlyokat is. A folyamat tehát nemcsak a gazdasági és népességi viszonyok horizontális átalakulásával járt együtt, hanem a korábbi társadalmi (falusi) közösségek felbomlásával; a korábbi életmód és értékrend területi struktúrája is megváltozott, módosult a természeti környezet és a gazdaság térségi viszonya stb. A tényezők horizontális átalakulását követve csak időbeli késéssel kezdődik meg a vertikális kapcsolatok újrarendeződése, az új egyensúlyi állapot felé vezető folyamatok megjelenése.

A területfejlesztés (mint a regionális folyamatokba való társadalmi beavatkozás) céljai abból is eredeztethetők, hogy a társadalom a vertikális egyensúly helyreállításának melyik lehetséges módját tartja alkalmazandónak. Ezek közül a gazdasági fejlettség területek közötti közelítése csak az egyik lehetséges megoldás (amely az elszivárgó erőforrások visszapótlását mozdítja elő a hátrányos helyzetủ térségekre). Az ilyen törekvések a gyakorlatban eddig kevés sikerrel jártak (StöhrTödling 1977), nem beszélve a rendszerváltáson átesett országokról, ahol az okok igen összetettek. Kivételektől eltekintve csak logikai lehetőség az egyensúly helyreállításának "negatív" módja, amely nem avatkozik be a spontán folyamatokba. Legkedvezőbb megoldás az „endogén” fejlődés (Rechnitzer 1995) előmozdítása, amelynek tengelyében a lokális egyensúlyt megvalósító fejlődés áll, a helyi tényezök kombinatív hasznositásának, az önkormányzás és preferenciáinak előtérbe állításával.

f) Végül az a kérdés vetődik fẹl, hogy mely tényezők milyen típusú vertikális kapcsolatai hozhatnak létre horizontálisan összefüggő régiókat? Néhány ilyen lehetöségre a különböző tartalmú egyensúlyok tárgyalása rámutatott. A tényezők tulajdonságai alapján a következő általános megállapítások tehetởk: A gazdaság a területi munkamegosztás elmélyüilése (,globalizáció”) miatt csak kevéssé alkalmas erre a szerepre. Ha a gazdaságot a természeti, a müvi környezet és a társadalom (egyes csoportjai) lokális kombinációjának tekintjük, akkor ez utóbbiak területi különbségei jórészt feloldódnak a gazdaság térbeni egyenlootlenségeiben - a társadalom anyagi életfeltételeire gyakorolt hatást tekintve. Ugyanakkor történelmileg tartósak az eszmék, értékek és bizonyos fokig az életmód térbeni eltérései. Horizontális kiterjedésuik igazodhat az adminisztratív struktúrákhoz (Ádám 1999), de független is lehet azoktól. Egyensúly-hiányt testesít meg, és így feszuiltségek forrása, ha valamely területen az állami jog- és preferenciarendszer ütközik az ott élö társadalom hagyományaival, értékeivel, eszméivel. Az ilyen típusú feszülltségek a vertikális kapcsolatokat tekintve harmonikus régiók szervezésével szüntethetők meg, amelyek esetenként átmetszik az adminisztratív határokat is. 


\section{Alkalmazási lehetöségek}

Hogyan alkalmazható a regionális szerkezeti (statikus egyensúlyi) modell a területfejlesztési politikában? Felépítéséből láthatóan teljesíti azt a követelményt, hogy a regionális politika ne korlátozódjék a gazdasági szférára, mivel a nem gazdasági, illetve a kulturális, szellemi tényezök is hordozhatnak feszültséget egymáshoz, illetve a gazdasági-természeti stb. tényezőkhöz mért viszonyukban. E feszültségek a gazdasági-anyagi szférában tapasztaltakhoz hasonlóan ugyancsak kedvezőtlenül hatnak az életminöségre.

Minőségi különbség mutatkozik a területi egyensúlyi növekedés sémája és a regionális szerkezeti (statikus egyensúlyi) modell között. Az utóbbi nem értelmezheti általánosan a területek közötti közelítést; a különbségek mérséklésének lehetôsége csak a modell gazdasági szférájában marad fenn továbbra is. Nyilvánvaló, hogy a szellemi-kulturális körre ez a folyamat nem vihetó át; a különbözö térségek szellemi kultúrája között a felszínen ugyan megnyilvánulhat bizonyos homogenizálódás, erősen kérdéses azonban, hogy ez fundamentálisan befolyásolhatja-e az eszméket, értékrendeket.

Szảmításba kell továbbá venni a kulturális tényezők lehetséges visszahatását a gazdaságra, amelyek esetleg a fejlődést gátolják. Kérdés, hogy ilyen esetekben megállja-e a helyét a gazdasági területi különbségek mérséklésére irányuló törekvés a regionális politika részéröl. Szélesebb perspektívában vizsgálva tehát megdőlhet a térségek közötti anyagi, gazdasági (életszínvonalbeli) különbségek mérséklésének általános elve; ez a preferencia csak meghatározott kulturális homogenitás mellett alkalmazható.

Viszonylag kisebb, etnikailag, kulturálisan kevéssé tagolt területek, országok viszonylatában a két modell közötti ellentmondás kevésbé élezödik ki, mint olyan, általában nagyobb térségek esetében, amelyeken eltérỏ eszmék, értékek, hagyományok, összefoglalóan kultúrák egymás mellett léteznek. Ez utóbbira jó példa az Európai Unió, mint gazdaságilag egységes, illetve egységesülő nagytér. Szellemi kultúrája azonban kevésbé tekinthetố egységesnek, jóllehet a jelenlegi unióhoz tartozó társadalmak értékrendje egyaránt a zsidó-keresztény (keresztyén) eszmeiség alapján fejlödött ki. Ugyanakkor a kereszténység sem egységes eszmei háttér, mélyebb elemzést igényelne annak feltárása, hogy a kulturális kuulönbségek befolyásolják-e az egyes országok unióba illeszkedését. A probléma súlya nőhet az Európai Unió hosszabb távon várható bövitésével, amelynek révén fokozódhat az értékrendek diverzitása, különösen, ha csatlakozásra iszlám eszmeiségú országokat is számitásba vesznek.

Végül szólnunk kell a „régiók Európája” jelszóval fémjelzett törekvés és a regionális szerkezeti (statikus egyensúlyi) modell lehetséges kapcsolatáról. Magától értetődik, hogy a korábban körvonalazott, funkcionálisnak nevezett régiók oszthatnák fel a gazdasági nagyteret, azaz olyan területi egységek képzödnének, amelyeken belül harmonikus viszony van a tényezök között, vagy az ilyen 
kapcsolat megteremthető az eszmék, értékek, életmód, gazdaság, társadalom, a müvi és a természeti környezet között. Ez a felosztás országhatárokat metszene át, korrigálná a hatalmi-politikai struktúra által okozott torzulásokat. Ugyanakkor megvetné az Európai Unió harmonikus területi fejlödésének alapjait. A kulturális tényezők szerepe fokozódnék, az értékrend és az életminöség fogalma szorosabb kapcsolatba kerülhetnek, az új modell alkalmazása ösztönözhetné az uniós területfejlesztési politika újragondolását is.

A régiók Európája akkor múködnék hatékonyan, ha a nevezett elvek szerinti regionalizálás együtt járna a hatalom decentralizációjával, az államhatárok szerepének háttérbe szorulásával, annak mintegy társadalmi-gazdasági alapját képezve. A megvalósítással szembeni várható erős ellenállás a mára anakronisztikussá vált „,nemzetállami” gondolatban gyökerezik. Hosszabb időtávon azonban a „régiók Európájának” aligha van alternatívája. A hatalom regionalizálása lehetôvé tenné - miként azt Segesváry Victor, volt ENSZ tanácsadó a Népszabadságnak adott interjújában kifejti - a „populista” demokráciáról a „republikánus” demokráciára való áttérést, amelynek hátterét az érintett társadalmi csoport közös értékrendje adja.

\section{Irodalom}

Ádám A. (1999) A közigazgatás értékkötöttsége az alkotmányos jogállamban. - Tér és Társadalom. 3. 19-36.0.

Bartke I. (1972) A tervezés kiinduló feltételei. Terïleti tervezés, tanácsi tervezés. - Kulcsár V. (szerk.), Közgazdasági és Jogi Könyvkiad6, Budapest. 91-108.o.

Bartke I. (1994) A területi (gazdasági) fejlődés társadalmi hajtóenói és állami szabályozása. - Tér és Társadalom. 3-4. 1-22.0.

Bartke I. (1999) A globalizáció regionális vetületei. - Tér és Társadalom. 4. 1-16.o.

Enyedi Gy. (1972) A társadalom és földrajzi környezete. - Földrajzi Közlemények. 4. 293-301.o.

Enyedi Gy. (1994) Fenntartható fejlỏdés - mit kell fenntartani? - Magyar Tudomány. 10. 1151-1160.o.

Enyedi Gy. (1996) Regionális folyamatok Magyarországon. Hilscher Rezső Szociálpolitikai Egyesület, Budapest.

Hajdú Z. (1995) A területfejlesztés problémakörének történelmi áttekintése. Területfejlesztés. - Bartke I. (szerk,), ELTE Eötvös Kiadó, Budapest. Egyetemi jegyzet. 168-186.o.

Horváth Gy. (1998) Európai regionális politika. Dialog Campus Kiadó, Budapest-Pécs.

Monori M. A.-Tillmann J. A. (2000) A globalizáció másik arca. Interjú Segesváry Victor volt ENSZ tanácsadóval a kultúrák párbeszédéről - Népszabadság. szeptember 16.

Rechnitzer J. (1993) Szétszakadás vagy felzárkózás. MTA Regionális Kutatások Központja, Györ.

Rechnitzer J. (1995) A teruletfejlesztés stratégiai alternatívái. Területfejlesztés. - Bartke I. (szerk.), ELTE Eötvös Kiadó, Budapest. Egyetemi jegyzet. 107-134.o.

Segesvary, V. (2000) Inter-Civilizational Relations and the Destiny of the West. University Press of America, New York-Oxford.

Stöhr, W.-Tödling, F. (1977) Spatial Equity - Some Anti-Theses to Current Regional Development Strategy. - Papers of the RSA. Vol. 38. 33-54.o.

Sztálin I. V. (1951) Elöadói beszéd a párt soronlevö feladatairól a nemzeti kérdés terén, az Oroszországi Kommunista (bolsevik) Párt X. kongresszusán (1921. március 8-16.) - Müvei. V. kötet. Szikra kiadás, Budapest. 35-47.0. 


\section{SPATIAL BALANCES}

\section{ISTVÁN BARTKE}

The promotion of a balanced spatial development is usually considered as the main task of regional development policy. To realise it, social intervention to the spontaneous regional processes is thought to be possible, moreover necessary even in market economy. The equalisation between territories is arising often however it is an effort of simplifying. By way of introduction we must make it absolutely clear that there is a qualitative difference between the social promotion of regional balanced growth and the equalisation of spatial disparity. We can not use these two expressions as synonyms. 